技術ノート

\title{
$\mathrm{He}^{3}$ クライオスタット
}

\section{I. $\mathrm{He}^{3}$ クライオスタットの問題点}

\author{
信 貴 豊 一 郎*
}

普通の液体 $\mathrm{He}^{4}$ を使用すれば簡単な装置で得られる 温度は略 $1.1^{\circ} \mathrm{K}$ どまりであるが，液体 $\mathrm{He}^{3}$ を利用す れば約 $0.3 \%$ までの低温度を容易に得ることができ る。充ず $\mathrm{He}^{3}$ の沸点は $3.2^{\circ} \mathrm{K}$ で $\mathrm{He}^{4}$ より低く, $1^{\circ} \mathrm{K}$ 以 下では液体 $\mathrm{He}^{4}$ に比べて桁違いに高い蒸気圧を持って いるため排気による冷却が容易である上に, 液体 $\mathrm{He}^{3}$ 性超流動を示さないので $\mathrm{He}^{4}$ に見られるような film flow の現象がなく, 液の表面からの蒸発ガスのみを 排気すればよいことがその理由である。また液体 $\mathrm{He}^{4}$ では film flow を防ぐため排気管の下端に湓路を備け

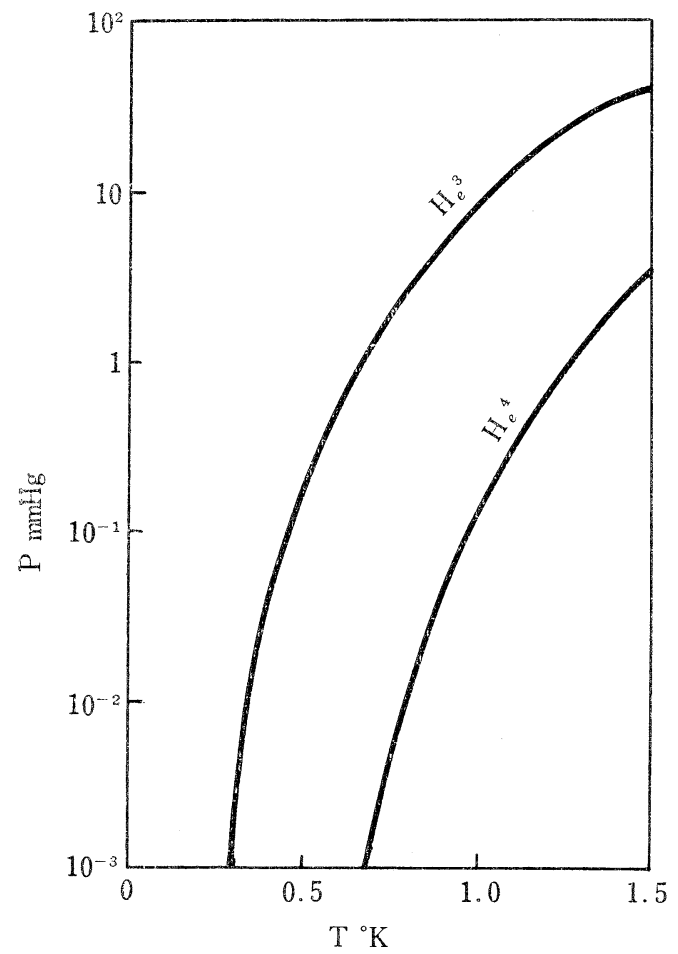

第 1 図 液体 $\mathrm{He}^{3}$ と液体 $\mathrm{He}^{4}$ の蒸気圧

* 大阪市立大学理学部

Vol. 3 No.5 (1968)
るのが普通であるが, $\mathrm{He}^{3}$ の場合にはとの必要がない ので排気管のコンダクタンスを大きくすることができ るのもとの利点である。

断熱消磁に上れば更に低い温度が得られるわけであ るが, 大型電磁石等の特殊な装置を必要としまた低温 度を一定に保てないと云う欠点が岀る。勿論 Daunt らによる周期的な磁気冷谏法1 を使光ば一定の温度を 保つこと悢不可能ではないが，装置の複雑さや吸収で きる熱量の大きさ等から考光て $\mathrm{He}^{3}$ クライオスタット の方がはるかに優れている。最近 $\mathrm{He}^{3}-\mathrm{He}^{4}$ 混合液を 使った希釈冷凍法 ${ }^{2)}$ が注目され始め， $0.01^{\circ} \mathrm{K}$ 亿至る極 低温が比較的簡単な装置で実現されている ${ }^{3)}$ が，もと もとこの方法が本領を発揮するのは略 $0.4^{\circ} \mathrm{K}$ 以下の温 度領域であって, これ以上の温度では第 2 図に示すよ う飞 $\mathrm{He}^{3}$ クライオスタットは吸収熱量がより大さい 上に，その装置や操作が簡単でありまた始動時間がは るが短い等の長所を持っている。結局 $1.2^{\circ} \mathrm{K} \sim 0.4 \% \mathrm{~K}$ の温度範囲では $\mathrm{He}^{3}$ クライオスタットが最も簡単でか つ優れた装置であると云うことができよう。

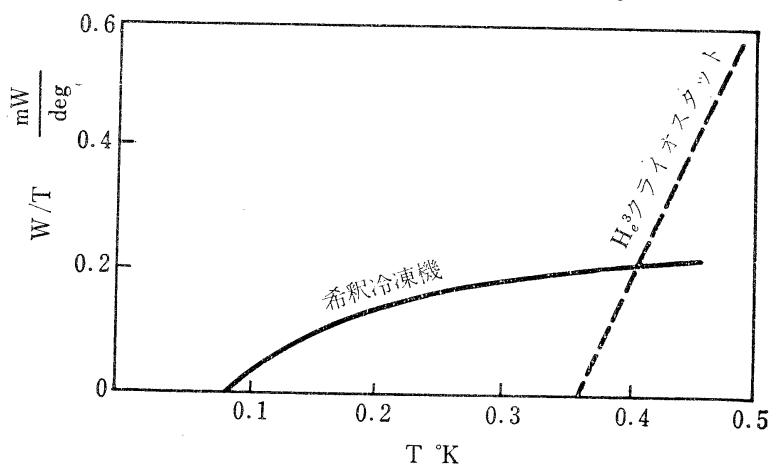

第 2 図 $\mathrm{He}^{3}$ クライオスタットと混合液を使った希釈 冷凍機との吸収エントロピーの此較。点線は $\mathrm{He}^{3}$ クライオスタット, 実線は同じスケールの希釈冷 凍機 (分溜室に加える熱量 $0.5 \mathrm{~mW}$ の場合) の吸 収エントロピーを示す (Hall らによる2) 。 


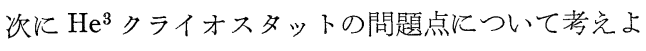
う。まず第一にクライオスタット内部の $\mathrm{He}^{3}$ 回路に洩 れがないようにすることが大切である。特に $\mathrm{He}^{3}$ の中 に $\mathrm{He}^{4}$ が洩れ込めば液体 $\mathrm{He}^{3}$ 中に $\mathrm{He}^{4}$ の濃度が増加 し，排気によって低温度を得ることが次第に困難とな って来る。また液体 $\mathrm{He}^{3}$ の蒸気圧によってその温度が 測定できる利点も失われてしまう。しかし $\mathrm{He}^{3}$ の外部 回路に“洩れなし”を要求する必要はない。僅かの空 気が混りこんでもクライオスタットを作動させれば低 温部に凝固するから, 実験終了後にそれを分離して取 り除くことができる。第二に液体 $\mathrm{He}^{3}$ と容器の壁との 間に境界熱抵抗が存在し，それが温度の二乗或は三乗 に逆比例するため最低温度附近では相当な大きさとな ることである。この障碍を克服するため容器の壁に非 常の多くのひだをつけてその表面積を堌す方法がとら れている。第三に液体 $\mathrm{He}^{3}$ を排気する導管のコンダク タンスをできるだけ大きくする必要がある。0. $3^{\circ} \mathrm{K} の$ 液体 $\mathrm{He}^{3}$ の蒸気圧は略 $1.5 \times 10^{-3} \mathrm{mmHg}$ で排気ポンプ 付近の圧力は更に小さくなっているから，排気回路の 殆どの部分で $\mathrm{He}^{3}$ ガスは分子流の領域にはいっている ことに注意すべきである。大抵の場合最低温度を決定 しているのは排気ポンプの能力ではなくて排気管のコ ンダクタンスである。第四に排気ポンプの問題である が回転ポンプのみを用いれば $0.45 \%$ 程度の低温が得 られ，これにブースターポンプを付加すれば $0.3^{\circ} \mathrm{K}$ に 到達することができる。この回転ポンプにはシャフト 部分扣よびケーシングに洩れのない特殊なるの゙)を使 用する必要が岁る。しかし臨界背圧の高い $(35 \mathrm{mmHg}$ 程度）水銀ブースターポンプら)を使光ば，回転ポンプ を使用しないで簡単確実で清浄な $\mathrm{He}^{3}$ 回路を作ること ができる。この場合 $\mathrm{He}^{3}$ の液化を迅速にするため液 体 $\mathrm{He}^{4}$ の温度を $1^{\circ} \mathrm{K}$ 付近まで下げて特くことが望末 しい。

$\mathrm{He}^{3}$ クライオスダットには, $1.3^{\circ} \mathrm{K} \sim 1^{\circ} \mathrm{K}$ の液体 $\mathrm{He}^{4}$ によって液化された数 $\mathrm{cc}$ の液体 $\mathrm{He}^{3}$ を排気してその 温度を下げ，排気されたガスはガス溜に収納してゆく 型式 (one shot type) と, 排気された $\mathrm{He}^{3}$ ガスを再 びクライオスタットに戻してコンデンサーの中で液化 乙移送弁を通して $\mathrm{He}^{3}$ 液溜飞供給する循環型式 $\left(\mathrm{He}^{3}\right.$ 冷凍機）とが岁る。液体 $\mathrm{He}^{4}$ を低温に保つ為に魔法瓶 に入れた液体 $\mathrm{He}^{4}$ を直接排気してもよいが（第 3 図 a ), 上り低温が容易飞得られるよ5飞第 3 図 b 如く 別の減圧 $\mathrm{He}^{4}$ 液溜を設けることもめる。 $\mathrm{He}^{3}$ クライオ スタットについてはPeshkovとZinovéva' ${ }^{6)}$, Taconis ${ }^{7)}$

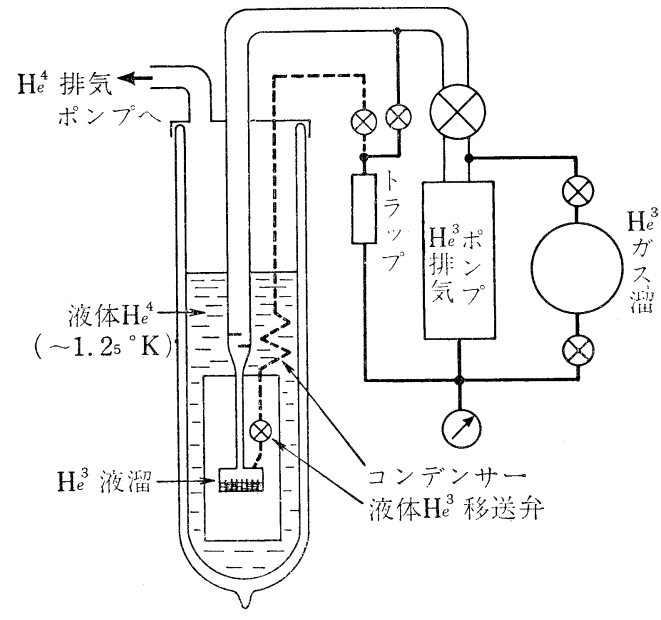

(a)

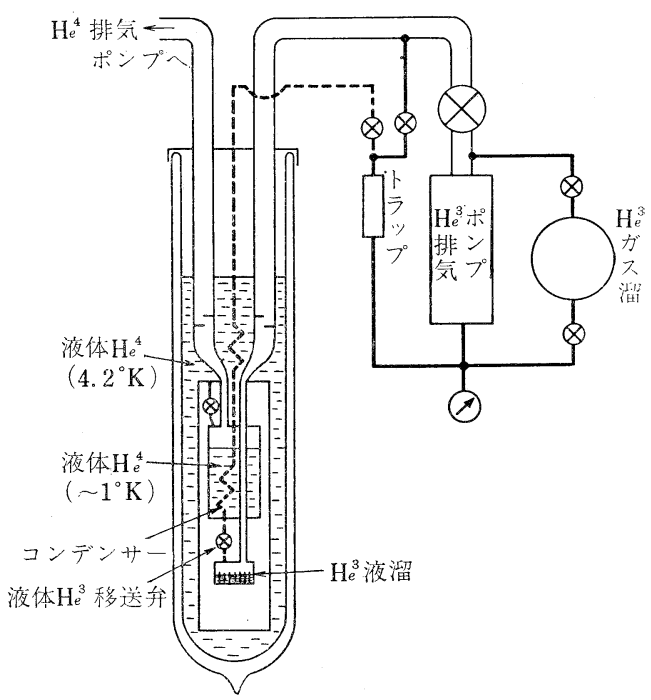

(b)

第 3 図 $\mathrm{He}^{3}$ クライオスタットの種々の型式。実 線で示しているのは one shot typeで, これと点 線の部分を加兄ると $\mathrm{He}^{3}$ 冷凍機になる。

あるいは Rose-Innes ${ }^{8)}$ による詳細な解説があるの で,ここでは立入った議論は避け最近の進歩も含めて 著者の見解を簡単に述べることにする。

液体 $\mathrm{He}^{3}$ は $\lambda$ 転移がないため, $1.3^{\circ} \mathrm{K}$ の液を排気し て $0.3^{\circ} \mathrm{K}$ に冷却しても 10〜20\% の液が蒸発するに過 ぎない。従がって one shot type の $\mathrm{He}^{3}$ クライオス タットでも熱流入が僅かであれば, 一度数 cc の液体 $\mathrm{He}^{3}$ を作ると 10 時間程度の実験を行ならことは十分 可能である。高背圧の水銀ブースターポンプのみで液 体 $\mathrm{He}^{3}$ の排気を行なう場合, 約 $1{ }^{\circ} \mathrm{K}$ に冷された小さ

低 温工学 
な溜に排気された $\mathrm{He}^{3}$ を一時的に液化して貯蔵するの が便利である ${ }^{9)}$ 。最近この種の装置で排気管の抵抗を 減らす目的で, 活性炭をクライオスタットの中に入れ て約 $1.3 \%$ に保ち，これを排気ポンプとして使ら方法

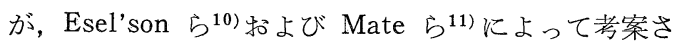
れた。この方法によれば, $\mathrm{He}^{3}$ の排気速度が非常に大き くなるので泠却能力は著しく增大する。40 gr の活性 炭を使用すると $10 \mathrm{cc}$ の液体 $\mathrm{He}^{3}$ を排気してもとの 排気能力は劣化しない。Mate らの装置では液体 $\mathrm{He}^{3}$ がなくなれば活性炭を常温部までひき上げ，脱着した $\mathrm{He}^{3}$ ガスを再び液化することができる。

$\mathrm{He}^{3}$ 冷谏機は one shot type に比べて装置が少し複 雑になるが, 大容量の実験装置を冷したり多量の熱流 入がある場合に有用である。この方法は少量の液体 $\mathrm{He}^{3}$ が溜れば作動し, また $\mathrm{He}^{3}$ 液化機構が完備して いるので, 実験を始めるまでの準備時間が非常に短く て済导長所がある。従がって必要とする $\mathrm{He}^{3}$ ガスの 量も僅かであり, Reich ら ${ }^{12)}$ や Rauch ${ }^{13)}$ は安価淿 製作できる簡単な装置を発表している。 $\mathrm{He}^{3}$ 冷凍機で は液化された $\mathrm{He}^{3}$ を液溜に送り込さ調節用移送弁が必 要であるが，液の流れを微細に調節できる工夫が必要 である。Ambler ら ${ }^{14)}$ は移送弁の代りに多孔質の金属 栓を利用して装置を簡易化した。毛細管にその内径と 殆ど同じ直径を持った線を挑入したものを同じ目的に 使用してもよい。この種の方法によれば装置は確かに 簡単になるが, constriction の適当なコンダクタンス は各装置によって異なるため, 始めに充分予備実験を 行なう必要がある。またこの部分は簡単に開塞する可 能性があるので, 装置の組立て拉よび運転に細心の注 意が要求される。

\section{参考文 献}

1) C. H. Heer, C. B. Barnes \& J. G. Daunt : Rev。 Sci. Instr. 25 (1954) 1088.

2) H. London, G. R. Clarke \& E. Mendoda : Phys. Rev. 128 (1962) 1992.

H. E. Hall, P. J. Ford \& K. Thompson : Cryogenics, April (1966) 80.

B. S. Neganov, N. Borisov \& M. Liburg : Soviet Phys. JETP 23 (1966) 959.

O. E. Vilches \& J. C. Wheatley : Phys。 Letters 24 A (1967) 440 ; 25 A (1967) 344.

3) J.C. Wheatley, O.E. Vilches \&W.R. Abel : privately circulated report.

4)この種の回転ポンプは大亜機械 K.K. (東京) るいは島津製作所（京都）で作られているっ

5）英国の Edwards High Vac. Ltd. でこの種の ポンプを製作している。

6) V. P. Peshkov \& K. N. Zinovéva : Repts. Progress in Phys. 22 (1959) 552.

7) K. W. Taconis : Progress in Low Temp. Phys. III, edited by C. J. Gorter, North-Holland Publishing Co. (Amsterdam) 1961, p. 153.

8) A. C. Rose-Innes : Low Temp. Techniques, English Univ. Press (London) 1964, p. 64.

9) G. T. Meaden \& T. Shigi : Cryogenics, April (1964) 90.

10) B. N. Esel'son, B. N. Lazarev \& A. D. Shvets : Cryogenics, Dec. (1963) 207.

11) C. F. Mate, R. Harris-Lowe, W. L. Davis \& J. G. Daunt : Rev. Sci. Instr. 36 (1965) 369.

12) H. A. Reich \& R. L. Garwin : Rev. Sci. Instr. 30 (1959) 7.

13) C. J.Rauch : Low Temp. Techniques, written by A. C. Rose-Innes, English Univ. Press (London) 1964, p. 77.

14) E. Ambler \& R. B. Dove : Rev. Sci. Instr. 32 (1961) 737.

\section{II. 日本で働いている $\mathrm{He}^{3}$ クライオスタット}

各グループに次のような内容で書いていただきました
1） cryostat（概略図，できれば実際の断面図も）
2）配管図（主要）
3）主要付属品の詳細（たとえば pumpのメーカー 特よび能力）
4）到達温度
5）冷却能力（各温度に打ける）
6) $\mathrm{He}^{4}$ の温度
7) $\mathrm{He}^{3}$ の量
8）測温方法
9）使用目的
10）運転状況和よび問題点
11）真空技術 


$\begin{array}{llll}\text { 武 } & \text { 藤 } & \text { 芳 } & \text { 雄 } \\ \text { 能登 } & \text { 宏 } & \text { 七 } \\ \text { 本 } & \text { 郷 } & & \text { 充 }\end{array}$

われわれが $\mathrm{He}^{3}$ クライオスタットの製作を計画し実 行に移したのは, 1961年であった。その後 2 年の苦学 が実を結び，1963 年暮に $0.38^{\circ} \mathrm{K}$ を得て完成した。こ の装置を初めに dilute alloy の電気抵抗の測定に使用 した後，小さな改造を行なって第 2 種超伝導体 In $\mathrm{Pb}$ の磁化測定に用いた。現在は比熱測定用のクライオス タットを作製中であり，さらにも 51 組の $\mathrm{He}^{3}$ クライ オスタットを計画中であるので，これらを合わせて報 告したい。

1. 磁化測定用クライオスタット1)

装置の大部分は金属性で第 1 図に示されるように断

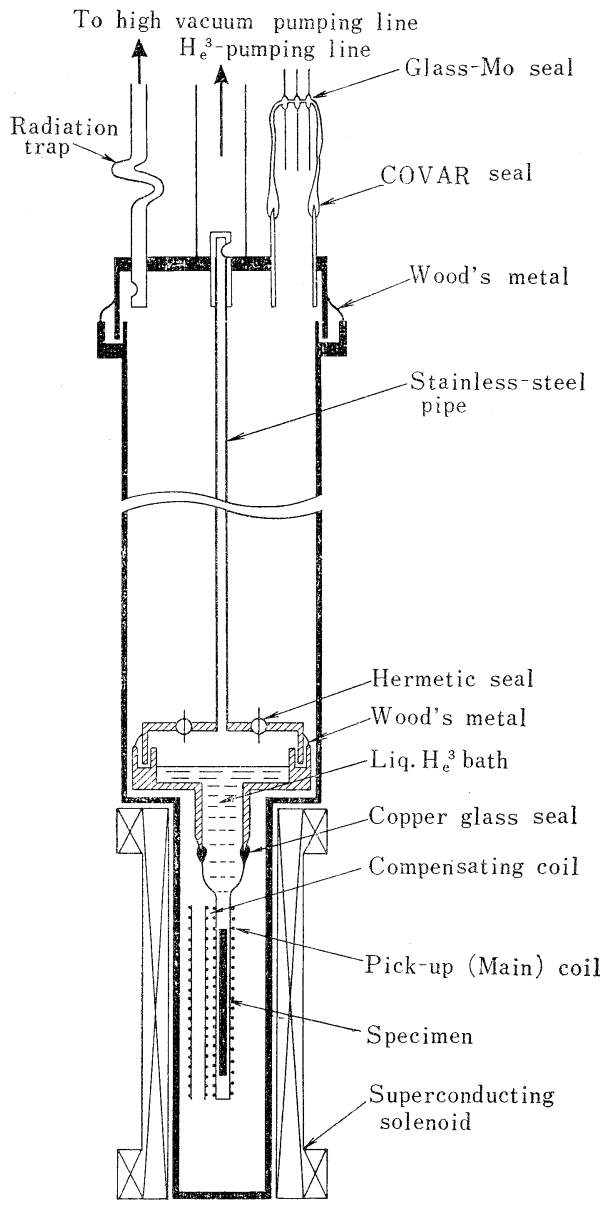

第 1 図
熱筀間部と容量約 $4 \mathrm{cc} の \mathrm{He}^{3}$ バスからなり, 試料は $\mathrm{He}^{3}$ で直接冷却される。直径 $3 \mathrm{~mm}$ の試料がそれ之略 同内径のガラス容器にセットされる。このガラス容器 は図のように銅ーガラス・シールで $\phi 10 \mathrm{~mm}$ の銅管 に, さらに $\phi 4 \mathrm{~cm}$ の真鍮管に接続する。この上部の ウッドメタルをとかして試料の交換学行なら。 $\mathrm{He}^{3}$ バ スは内径 $4.5 \mathrm{~mm}$ のステンレス管で，常温部の $\mathrm{He}^{3}$ 用 配管と連結する。連結部には輻射シールドをつける。 温度の測定には $0.55^{\circ} \mathrm{K}$ まで $\mathrm{He}^{3}$ の蒸気圧を用い, $0.55 \%$ 以下はカーボン抵抗温度計を主として用いた。 断熱空間にはピックアップコイル（メインコイルとコ ンペンセイションコイル）学括いた（測定法は交献 1 を参照されたい)。クライオスタットは真鍮で製作し た。断熱容器よりのリード線の出口は図のようにガラ スで作り，銀紙をかぶせて輻射熱を防いだ(これを急 ると $0.6 \circ \mathrm{K}$ までしか下がらない)。磁化測定のために スーパーコン A 25 の NbZr 超伝導ソレノイドを断熱 容器の外側に执いた。ソレノイドの内径は $29 \mathrm{~mm}$ シ ムをつけることにより，長さ $6 \mathrm{~cm}$ にわたって $10^{-3} の$ 磁場均一度を保った。

配管の系統図を第 2 図に示した。クライオスタット はアングル台に固定する。ポンプを除いて全系はアン グル台上に配置した。 $\mathrm{He}^{3}$ 系の主配管は $\phi 60 \mathrm{~mm}$, その他の配管は $\phi 20 \mathrm{~mm}$ である。 $\mathrm{He}^{3}$ 系の真空度は $10^{-6} \mathrm{mmHg}$ である。ポンプは振動源以ならないよう に配置に注意した。 $\mathrm{He}^{3}$ 減压用ポンプは小さな大亜製 油拡散ポンプと大重製油回転ポンプそ用いた。後者は エアタイトで油中に浸っている。断熱系には主配管中 $75 \mathrm{~mm}$ ，その他の配管には $\phi 10 \mathrm{~mm}$ 銅管を用いた。 $\mathrm{He}^{4}$ の排気系には $\phi 75 \mathrm{~mm}$ 銅管を用いた。そ他の 脚詳細は第 2 図に記入した。

最低到達温度は $0.38^{\circ} \mathrm{K} 。 \mathrm{He}^{3}$ 娄 $2 \mathrm{cc}$ 液化して数時 間の実験が可能でめる(外側の液体 $\mathrm{He}^{4}$ のるつ時間で 決をる)。 $\mathrm{He}^{4}$ の温度は約 $1.1^{\circ} \mathrm{K}, \mathrm{He}^{3}$ ガスを $1 / 4$ 気 圧で $5.6 l$ 用いた。約 2 年間にわたる使用（数十回の 液化）で, ロスは認められなかった。

2. 電気抵抗用クライオスタット

電気抵抗を測定する際は上述の $\mathrm{He}^{3}$ 容器を交換し, 第 3 図のよ5な全金属性の短ざく型の容器を使用し 


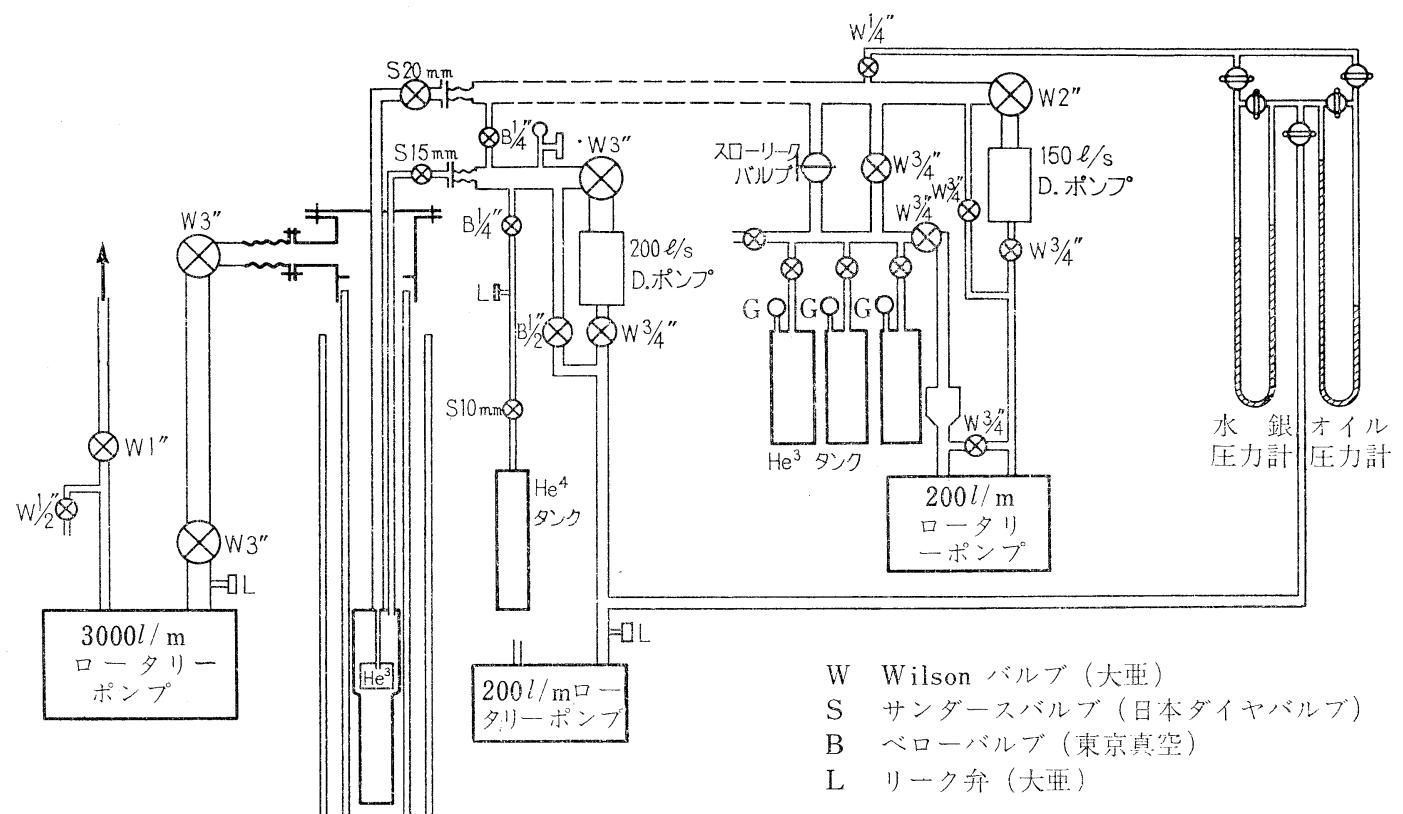

G 圧力ゲージ

た。試料は容器の内幅に合わせたアクリル板にセット した。リード線の取り出し口には, 図のようにハーメ チックシール（NEC A110）を用いた。

3. 比熱用クライオスタット

第 4 図に示されるような比熱測定用容器を準備中で 岕る。前述のソレノイドを使用して超伝導体の磁場中

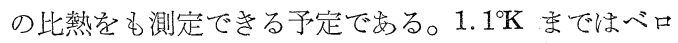
一ズを用いたメカニカルヒートスウィッチで試料を冷 却し,さらに, $0.4^{\circ} \mathrm{K}$ 采で超伝導ヒートスウィッチ $(\mathrm{Pb})$ で冷却する。

\section{4. 磁気抵抗用クライオスタット}

実験量の增加にともない，も5 1 組の $\mathrm{He}^{3}$ の装置を 組立て中である。新装置には油拡散ポンプは用いずに welch の油回䎐ポンプを使用する。横磁場での磁気抵 抗を測定するためのクライオスタットで, 電磁石のポ ールピース間隙の関係から, クライオスタットの外径 は $26 \mathrm{~mm}$ である。リード線の出口はすべてハーメチッ クシールとした。

$$
\text { 参考文献 }
$$

1) K. Noto, Y. Muto and T. Fukuroi : J. Phys. Soc. Japan 21 (1966) 2122.

Vol. 3 No. 5 (1968)

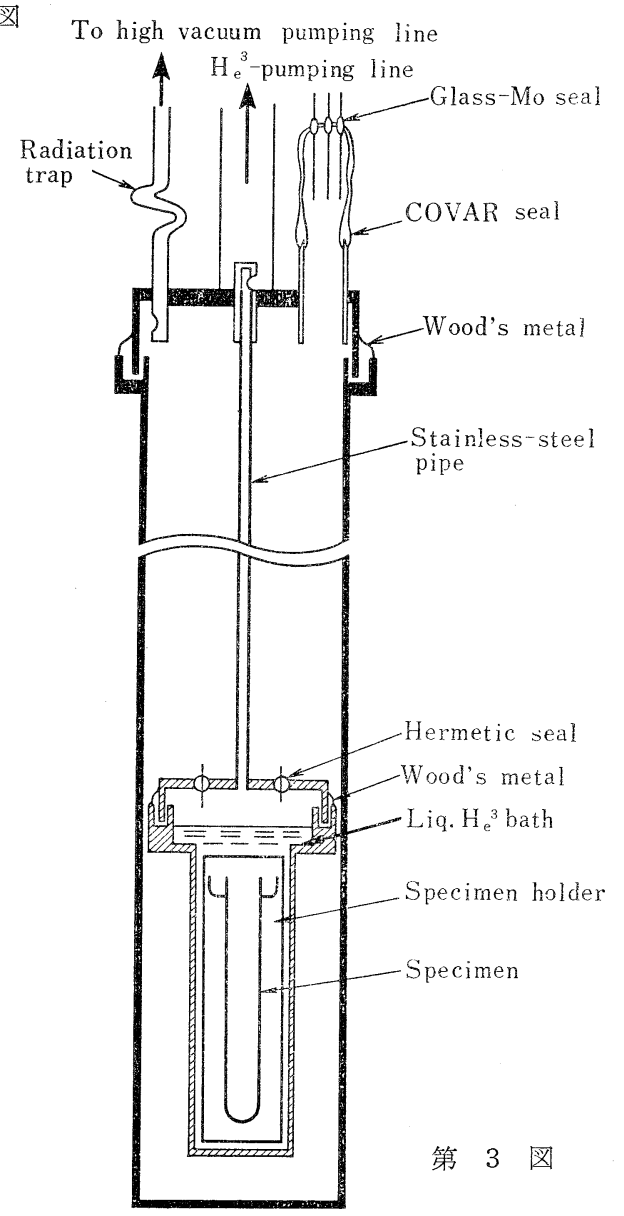




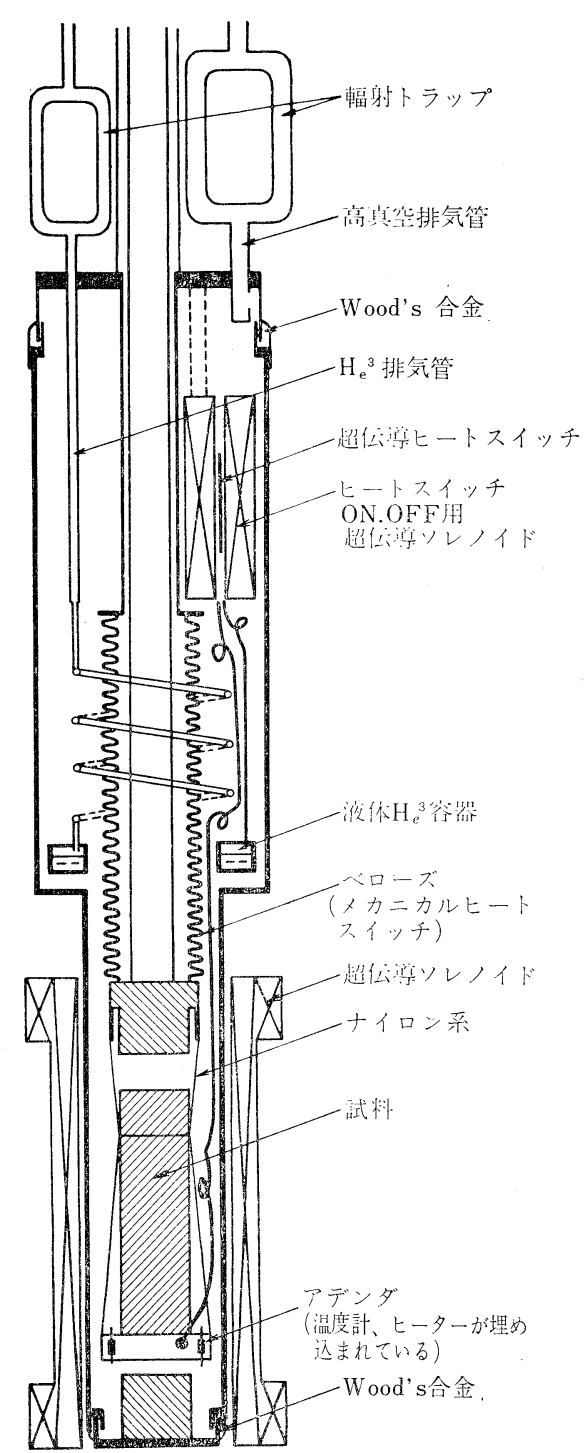

第 4 図
$\mathrm{Ga}$ 単結晶の超伝導エネルギーギャップの異方性を トンネル効果によって測定する目的で, $\mathrm{He}^{3}$ を用いた クライオスタットを製作した。

第 1 図はクライオスタットの概略図である。外径 $31 \mathrm{~mm}$, 高さ $175 \mathrm{~mm}$ で, この外側に, $\mathrm{He}^{4}$ bath と の断熱のための外筒（直径 $40 \mathrm{~mm}$, 高さ約 $40 \mathrm{~cm}$ ) が

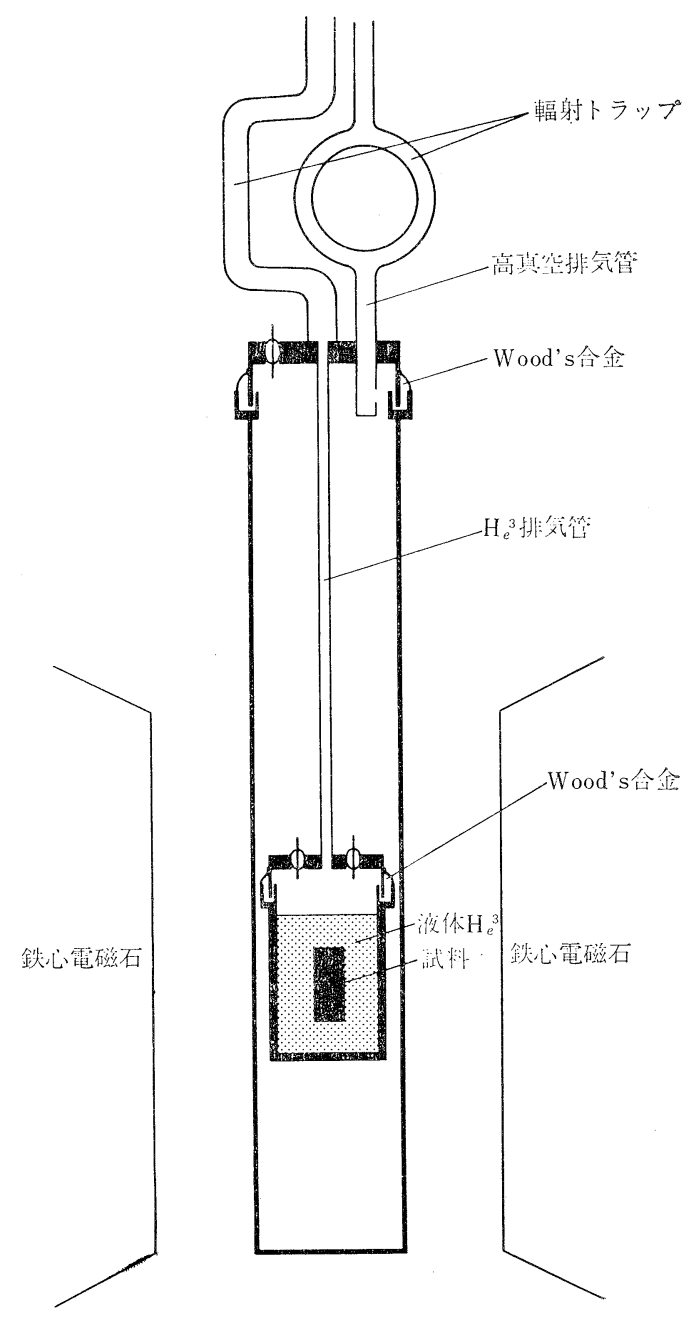

第 5 図

ある。外筒，内筒とも主として銅製で，着脱する部分 の上下には, ステンレスの帯を入れて, 着脱作業を容 易に，短時間でできるようにしている。

試料は, 直径 $10 \mathrm{~mm}$ 程度の $\mathrm{Ga}$ 単結晶の上面に, $\mathrm{Ga}-\mathrm{GaO}_{x}-\mathrm{Pb}$ 膜のトンネル接合を作ったもので, 黄銅 製の保持金具中に和さまっている。保持金具には，帯 


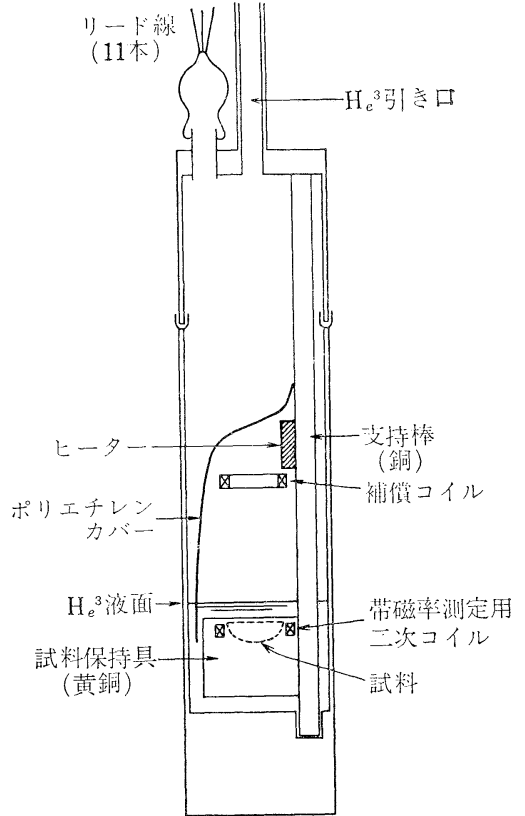

第 1 図トンネル效果測定用クライオス タットの概略

Exchange gas

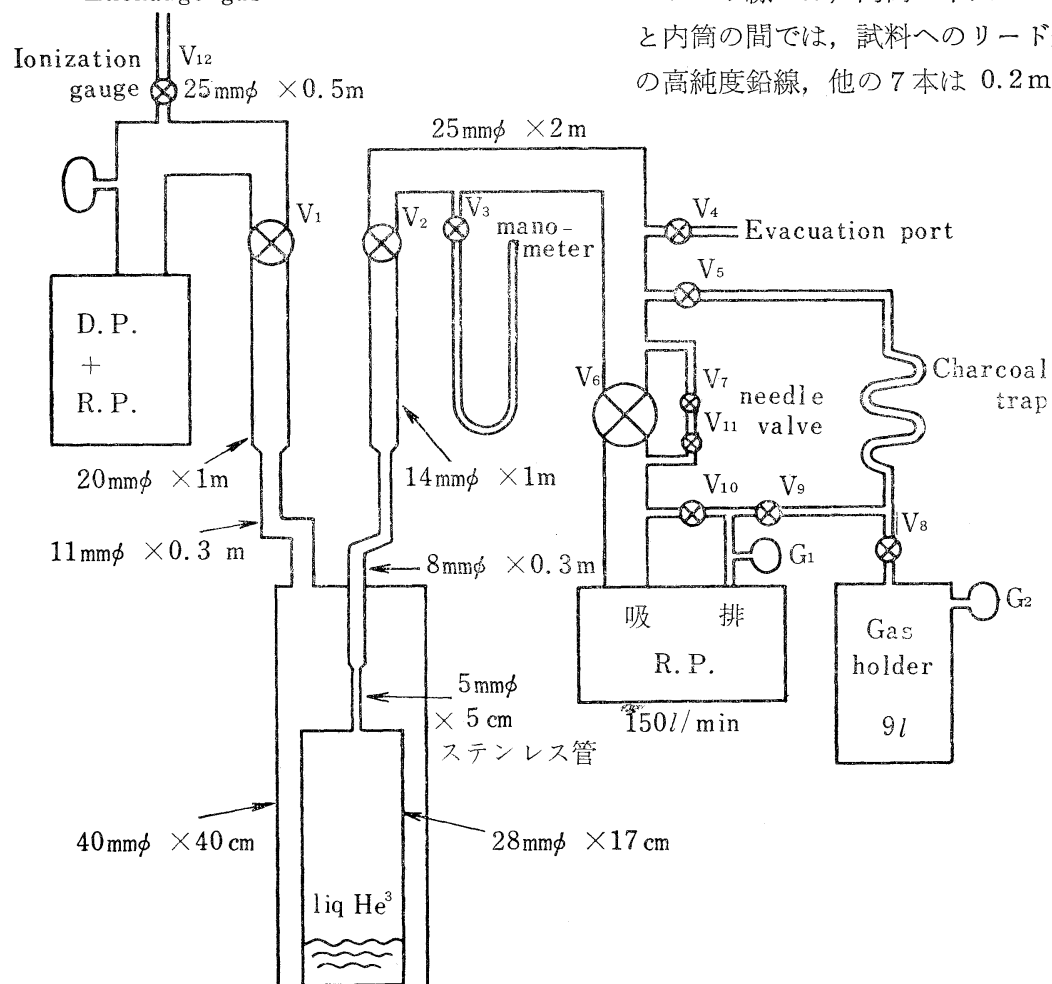

第 2 図 $\mathrm{He}^{3}$ 排気 系
磁率測定用の二次コイルが埋込んであり，これによっ て $\mathrm{Ga}$ の $\mathrm{Tc}$ を測定する。

温度は, $\mathrm{He}^{3}$ の蒸気圧を石英のブルドン管で 0.01 $\mathrm{mmHg}$ 交で読んで測定する。このゲージによって， $1{ }^{\circ} \mathrm{K}$ 付近では $0.3 \mathrm{mdeg}$ 程度まで, 再現性よく測定で きる。 $0.6^{\circ} \mathrm{K}$ 以下では, 蒸気圧を回転マクレオド真空 計によって読んでいる。クライオスタット内の温度の 勾配を避㐌るために, 試料は $\mathrm{He}^{3}$ 液中に浸してある。 試料の形などの関係で, あ屯り dead volume を小さ くできないので, 試料を液中に浸すために $\mathrm{He}^{3}$ を $7.5 l$ （標準状態で）汇ど用いている。

$\mathrm{Ga}$ は $30^{\circ} \mathrm{C}$ でとけるため，試料を交換するとさ，外 筒, 内筒を着脱する際のハンダゴテの熱でとけないよ うにするために，クライオスタット全体の長さはやや 長くなっている。そのために dead volume が增えて 液化しない $\mathrm{He}^{3}$ が $1 l$ ほどになるがやむを得ない。 筒の着脱の祭には，上下両端にカーゼを巻きつけ，そ れにアセトンをしみこませて，アセトンの蒸発熱によ って試料の温度上年を和さえている。ポリエチレンの カバーは，着脱作業の際，ハンダのやになどで試料を よごさないためにつけている。

リード線には，内筒の中は $0.23 \mathrm{~mm} \phi の$ 銅線，外筒 と内筒の間では，試料へのリード線 4 本は $0.25 \mathrm{~mm} \phi$ の高純度鉛線，他の 7 本は $0.2 \mathrm{~mm} \phi$ のマンガニン線 
を使用している。リード線の引出口は，白金に軟質ガ ラスを融着したものである。

配管は第 2 図に示す。 $V_{1}$ より左側の部分は, 内筒と 外筒の間を断熱するための排気装置で，400 l/sec の拡 散ポンプと $200 \mathrm{l} / \mathrm{min}$ の油回転ポンプの組合せである。 常温に执いて exchange gas を数 $\mathrm{cm} \mathrm{Hg}$ 入れた場合 $\mathrm{He}^{4}$ bath の温度 $1.15 \sim 1.17^{\circ} \mathrm{K}$ 飞执いて, 約 30 分 で断熱させることができる。 $\mathrm{He}^{3}$ の排気装置は $\mathrm{V}_{2}$ よ り右側の部分である。バルブ $\mathrm{V}_{1}, \mathrm{~V}_{2}$ より下の部分が デュワーに付いて括り， $\mathrm{V}_{1}, \mathrm{~V}_{2}$ のところで排気装置か ら切放すことができる。

$\mathrm{He}^{3}$ を排気するポンプは，大巠真空技研製 $150 \mathrm{l} / \mathrm{min}$ の油回転ポンプで，ポンプの外函は鋼板の溶接に上っ て組立てられ，回転軸のシールは二重の○リングによ っている。バルブ類は, $V_{7}$ が $1 / 4^{\prime \prime}=$ ードルバルブの 他は全て○リングシールの L 型バルブで, $\mathrm{V}_{1}, \mathrm{~V}_{2}$ が $5 / 8^{\prime \prime}, \mathrm{V}_{6}$ が $1^{\prime \prime}$, その他が $3 / 8^{\prime \prime}$ のもので, $\mathrm{V}_{6}$ 以外は 自家製である。

$\mathrm{He}^{4}$ bath の最低温度 $1.15 \sim 1.17{ }^{\circ} \mathrm{K}$ 亿和いて, クラ イオスタットの到達最低温度は, 測定電流に上る発熱 が $3 \mu \mathrm{W}$ 程度のとき 0.36 踦る。最低温度に達す
るまでに約 2 時間を要する。液化した $\mathrm{He}^{3}$ は約 $8 \mathrm{cc}$ ほどになる。一度 $\mathrm{He}^{3}$ を液化すれば，外側の $\mathrm{He}^{4}$ が なくなる栾で（15〜20 時間）実験を継続できる。な

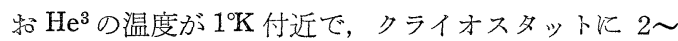
$3 \mu \mathrm{W}$ の熱の流入があるが，これは主に鉛線から入る ように思われる。

蒸気圧を測定する枝は $\mathrm{V}_{3}$ 亿つながって物り，直接 クライオスタットからのびていないが，最低温度を除 いては, 温度を一定に保つために要する $\mathrm{He}^{3}$ の蒸発量 は極めてわずかであり，実用上差支えない。ただし， 最低温度をきるるは， $\mathrm{V}_{6}$ を閉じたときの蒸気圧の 時間変化から外挿している。

クライオスタット款よび排気装置の組立てには，と りはずしをすることがない部分は低温銀ろう，つけは ずしをする部分はハンダを用いている。特に試料の交 換をするために着脱する部分については，ウッドメタ ルなどの低温ハンダよりも，ふつうの $50 \%$ Sn 入り Solderite の方が, 作業が手早く確実にできる点で, 好都合でめる。現在まで 40 回余の運転では, 連成計 $\mathrm{G}_{1}, \mathrm{G}_{2}$ でみる限り $\mathrm{He}^{3}$ の減少はみとめられない。

\section{名古屋大学理学部益田研究室}

$\begin{array}{llll}\text { 益田 } & \text { 義 } & \text { 賀 } \\ \text { 馬 宮 孝 } & \text { 好 }\end{array}$

$\mathrm{He}^{3}$ を用いるクライオスタットを製作して, 超伝導 体の核磁気緩和を測定したのは, 添 10 年も昔のこ とであるが, 最近, 超伝導体の比熱測定のために同様 なクライオスタットを製作したので，㐫わせて報告し たい。いずれも構造が簡単で操作が容易であることを 目祭とした。

1. 核磁気緩和測定用のクライオスタットを第 1 図 北示す。全ガラス製で，その詳細は文献1亿詳しい。 $\mathrm{He}^{3}$ 排気装置は Keesom と Seidel $\left.{ }^{2}\right)$ ののと違って油 回転ポンプだけを使用し，可動ラックに組込んで移動 可能とし, 他の実験装置にのリング, 真空用フランジ, クランプにより簡単に接続できるようにした。Welch 1400 油回転ポンプ（排気量 $21 \mathrm{l} / \mathrm{min}$ ）のシャフトシー ルをグラファイト製に変光, ポンプ全体を油槽につけ て, $\mathrm{He}^{3}$ ガスの漏れを防いだ。この方法は, Reich と Garwin ${ }^{3)}$ のポンプよりも安心でさる。 $\mathrm{He}^{3}$ 部分には
鉄アンモニア明ばんを入れて岕り，実験開始後は温度 測定に用いるが，最初は $1.2 \% ， 5 \mathrm{kG}$ より出発して䉍 単な断熱消磁を行なって, $\mathrm{He}^{3}$ を液化するのに使用す る。拡散ポンプを使用しないでも，この方法で $0.35^{\circ} \mathrm{K}$ に到達した。試料は $\mathrm{He}^{3}$ につかっている。 $\mathrm{He}^{3}$ ガスの

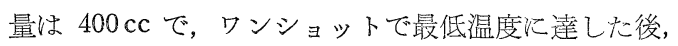
1 時間程度の実験が可能でめった。この装置を製作し た当時は, $\mathrm{He}^{3}$ ガスの価格は $1 \mathrm{cc} \mathrm{STP} \mathrm{が} 1$ ドル 50 セントで岁った。高価であるばかりでなく生産が追い つかなかったので，入手ははなはだ困難であった。

2. 比熱測定用のクライオスタットを第 2 図に示 す。全金属製で, 外側断熱空間 $(\mathrm{G}-\mathrm{H})$, 内部試料室 (H内), 容積約 $4 \mathrm{cc}$ の $\mathrm{He}^{3}$ の溜 (I) の 3 部分から 成り立っている。排気管は全部 $\mathrm{CuNi}$ 管で, 外筒飞 5 $\phi$ 管 (D) が, 内筒に $5 \phi$ 管 (C) が各 1 本, $\mathrm{He}^{3}$ 溜 には $8 \phi$ 管 (A) と $5 \phi$ 管 (B) が各1本ついてい 


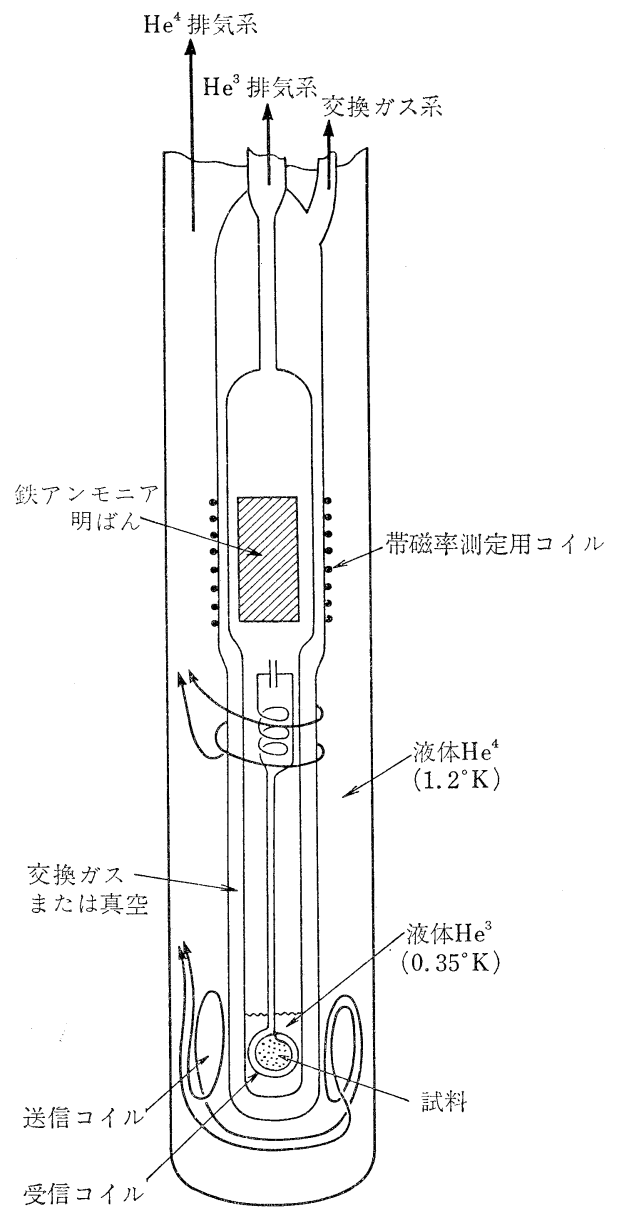

第 1 図 核磁気緩和用 $\mathrm{He}^{3}$ クライオスタット

る。 $\mathrm{A}$ はっぱら $\mathrm{He}^{3}$ 排気用に, B は蒸気圧測定用, 循環式液化用などに使用する。試料（K）特よびアデ ンダ（M）と $\mathrm{He}^{3}$ の溜とを熱的に接触させたり断った りするためには，デュワーキャップの上部からステン レス線（E）により，メカニカルヒートスイッチ（J) を動作させる。アデンダ特よびヒートスイッチは金メ ッキしてある。アデンダは8本のナイロン糸（N）で つり下げてある。外筒 $(\mathrm{G})$ と内筒 $(\mathrm{H})$ の上部には ハーメチックシール（NEC-A 110）がそれぞれ8個つ いて晾り，内外筒間，内筒と試料温度計（L）特よび ヒーター (M) との間は, NbZr 線 $0.1 \phi($ 各 $1 \mathrm{~m}$ ) で 接続してある。このクライオスタットは, 比熱測定以 外に带磁率測定にも使用できる。内筒内部のナイロン 糸固定枠 (P) と $\mathrm{NbZr}$ 線固定枠 (Q) を利用して, 温度測定用コイルと試料の帯磁率測定用コイルを固定 する。この場合には, 交換ガスとして, $\mathrm{He}^{3}$ を内筒に

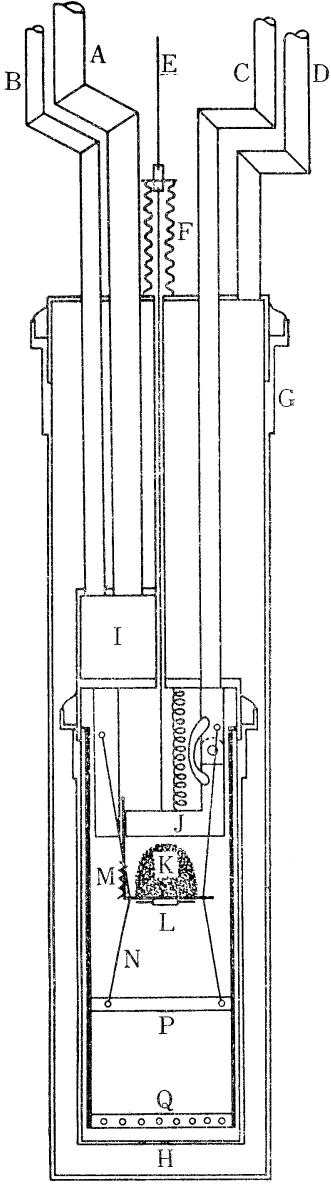

第 2 図比熱用 $\mathrm{He}^{3}$ クライオスタット $\mathrm{A}: \mathrm{He}^{3}$ 減圧用 $8 \phi$ 管， B : 循環用李たはマ, メータ一用 $\mathrm{He}^{3} 5 \phi$ 管, C : 試料室用 $5 \phi$ 管, $\mathrm{D}$ ：断熱空間用 $5 \phi$ 管， E：メカニカルヒート スイッチのステンレス線, $\mathrm{F}$ ：べローズ， G： 外筒, $\mathrm{H}$ : 内筒, $\mathrm{I}: \mathrm{He}^{3}$ 溜, $\mathrm{J}:$ $:$ メカル ヒートスイッチ, $\mathrm{K}$ : 試料, $\mathrm{L}$ : 温度計, $\mathrm{M}$ ： アデンダ抒よびヒーター， N ：試料つり下げ用 ナイロン系, $\mathrm{P}$ ：ナイロン糸固定枠, $\mathrm{Q}: \mathrm{Nb}$ $\mathrm{Zr}$ 線固定枠

入れる。

配管は第 3 図に示す。デュワーは $21 \mathrm{kG}$ の電磁石 の $9 \mathrm{~cm}$ ギャップ間にはいるように，電磁石上に組ん だアングルからつり下げる。第 3 図でジョイント (L) より右側の部分の排気系は同じアングル上に組んで女. る。左側の $\mathrm{He}^{3}$ 排気装置は可動ラックに組み, 他の 実験装置にも共用できるようにしてある。 $\mathrm{He}^{3}$ 主排気 管は $18 \phi$ 銅管で長さは約 $2 \mathrm{~m}$, 他は $10 \phi$ 銅管々使 用している。 


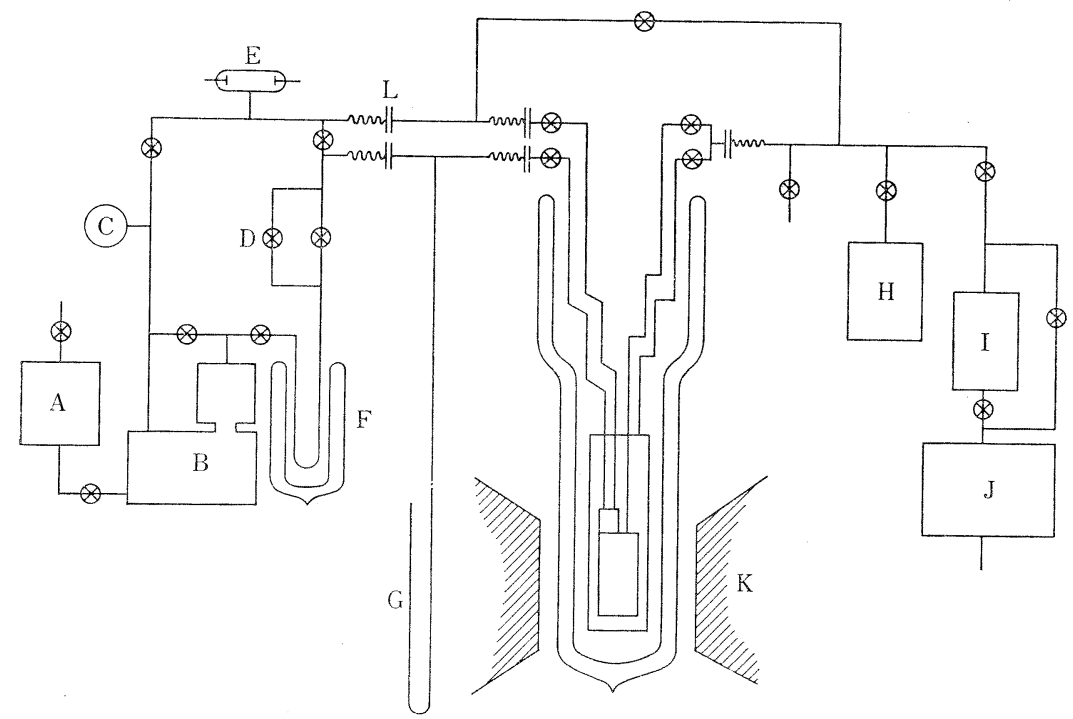

第 3 図 $\mathrm{He}^{3}$ 排気系

$\mathrm{A}: 4 l$ 油溜, B : $4 l$ ガス溜つき $150 l / \mathrm{min}$ 回転ポンプ, C $: 1$ 気圧ブルドンゲ ージ, D : ニードルバルブ, E : ガイスラー管, F：液体窒素トラップ, G：オ イル抒よび水銀マノメーター, $\mathrm{H}: \mathrm{He}^{4}$ ガス溜, $\mathrm{I}: 200 \mathrm{l} / \mathrm{sec}$ 拡散ポンプ, ノ: $200 \mathrm{l} / \mathrm{min}$ 回転ポンブ, $\mathrm{K}: 9 \mathrm{~cm}$ ギャップ, $21 \mathrm{kG}$ 電磁石

$\mathrm{He}^{3}$ 減圧ポンプには, $4 l$ の容積の $\mathrm{He}^{3}$ 溜をつけた 油回転ポンプだけを用いた。軸二重 ○リングシールで 排気量は $150 \mathrm{l} / \mathrm{min}$ 。大亜製。バルブ類は主排気管に $15 \phi$ 用の，他は $10 \phi$ 用のし形ベローバルブを用いた。 東理社製。

最低到達温度は $0.36^{\circ} \mathrm{K}$ 。比熱測定の場合を例にと ると, ワンショットで液化した $\mathrm{He}^{3}$ (4cc 程度)を用 いて約 $30 \mathrm{~g}$ の $\mathrm{Ta}$ を $4^{\circ} \mathrm{K}$ から $0.4^{\circ} \mathrm{K}$ までくり返し 数回冷却した後でも, 外側の $\mathrm{He}^{4}$ 液体が残っている 限り (約 12 時間), $\mathrm{He}^{3}$ は $3 \mathrm{cc}$ 程度残っている。 $\mathrm{He}^{4}$ の温度は $1.05 〜 1.10^{\circ} \mathrm{K}$ 。用いた $\mathrm{He}^{3}$ ガスの量は 0.85 気圧で $4.5 l 。 \mathrm{He}^{3}$ 温度はオイルマノメーター括よび 鉄アンモニア明ばんの帯磁率で測定する。

過去約 10 回の実験の結果, ブルドンゲージ和よび マノメーターで見る限り $\mathrm{He}^{3}$ の減りは認められない。 前述のよ5に $\mathrm{He}^{3}$ 液体そのものは $0.36^{\circ} \mathrm{K}$ まで下がる が，試料へはヒートスイッチを通じるので，到達温度 は $0.4^{\circ} \mathrm{K}$ である。しかし，ヒートスイッチを開いた とき, 摩擦熱などで試料の温度が, 上昇し, 比熱測定は,
$0.6 \%$ 以上の温度でないとできない。ヒートスイッチ

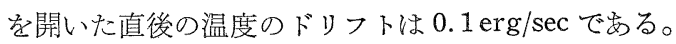
摩擦熱の発生を少なくするためにヒートスイッチを改 良し, 試料のつるし万を工夫し, 試料の量を増すなど して，もら少し低い温度から測定できるようにした Wo

クライオスタット特よび $\mathrm{He}^{3}$ 排気装置は, 銀ろう， 真らゅうろう，融点の異なる種々のハンダを使用して いずれも $4 \times 10^{-10} \mathrm{mmHg} l / \mathrm{sec}$ の $\mathrm{He}$ リークデテク ター (CEC 製) で漏れが認められない程度製作し た。

\section{参考 文 献}

1) Y. Masuda and A. G. Redfield : Phys. Rev. 125 (1962) 159.

2) P.H.Keesom and G. Seidel : Rev. Sci. Instr. 29 (1959) 606.

3) H. A. Reich and R. L. Garwin : Rev. Sci. Instr. 30 (1959) 7. 
大阪市立大学理学部奥田研究室

児玉 隆 夫

[目的および特徵】この $\mathrm{He}^{3}$ 冷凍機は, $1^{\circ} \mathrm{K}$ 以下に 括ける超伝導薄膜の性質を調べる目的で作られた。薄 膜は一たん冷却すると調べたい全ての測定を行なら必 要があるので, クライオスタットは長時間（1日～2 日）の連続軍転に堪えねばならない。 $\mathrm{He}^{3}$ のガスが凝 縮する減压 $\mathrm{He}^{4}$ 液溜が, 常飞 $1^{\circ} \mathrm{K}$ 付近飞保たれて特 ればこれが可能となる。この装置の特徽は減圧 $\mathrm{He}^{4}$ 液 を $1^{\circ} \mathrm{K}$ 飞保ったます，液体 $\mathrm{He}^{4}$ を連続的飞移送でき ることで，実験の始めに移送弁を適当にセットして招 け注, 減压 $\mathrm{He}^{4}$ 液溜の液量は常に一定に保たれる。 したがって， $4.2^{\circ} \mathrm{K} の \mathrm{He}$ 液を時々外部からサイフォ ンで補給しさ党すれば，いくらでも長時間の連続運転
を行ならことができる。

$\mathrm{He}^{3}$ のガスは，背压が $35 \mathrm{mmHg}$ まで働く水銀拡散 ブスターポンプを用いて循環させるが，もちろん循環 させないで使用することもできる。

\section{[装置の概要]}

この装置の本体とこれの主要配管図を第 1 図に示し た。特に注意した点は，(1) 室温からの熱輻射の遮蔽 (2) $\mathrm{He}^{3}$ 特よび $\mathrm{He}^{4}$ の排気パイプのコンダクタンス (3) $4.2^{\circ} \mathrm{K}$ の $\mathrm{He}$ 液を $1^{\circ} \mathrm{K}$ の減圧 $\mathrm{He}^{4}$ 液溜飞移送す る方法，（4） $\mathrm{He}^{3}$ ガスの予冷と液化機棈，(5) $\mathrm{He}^{3}$ の 液と液溜との熱接触, などである。（1）については極 低温部に至るパイプが最も問題になるので, 途中に輻

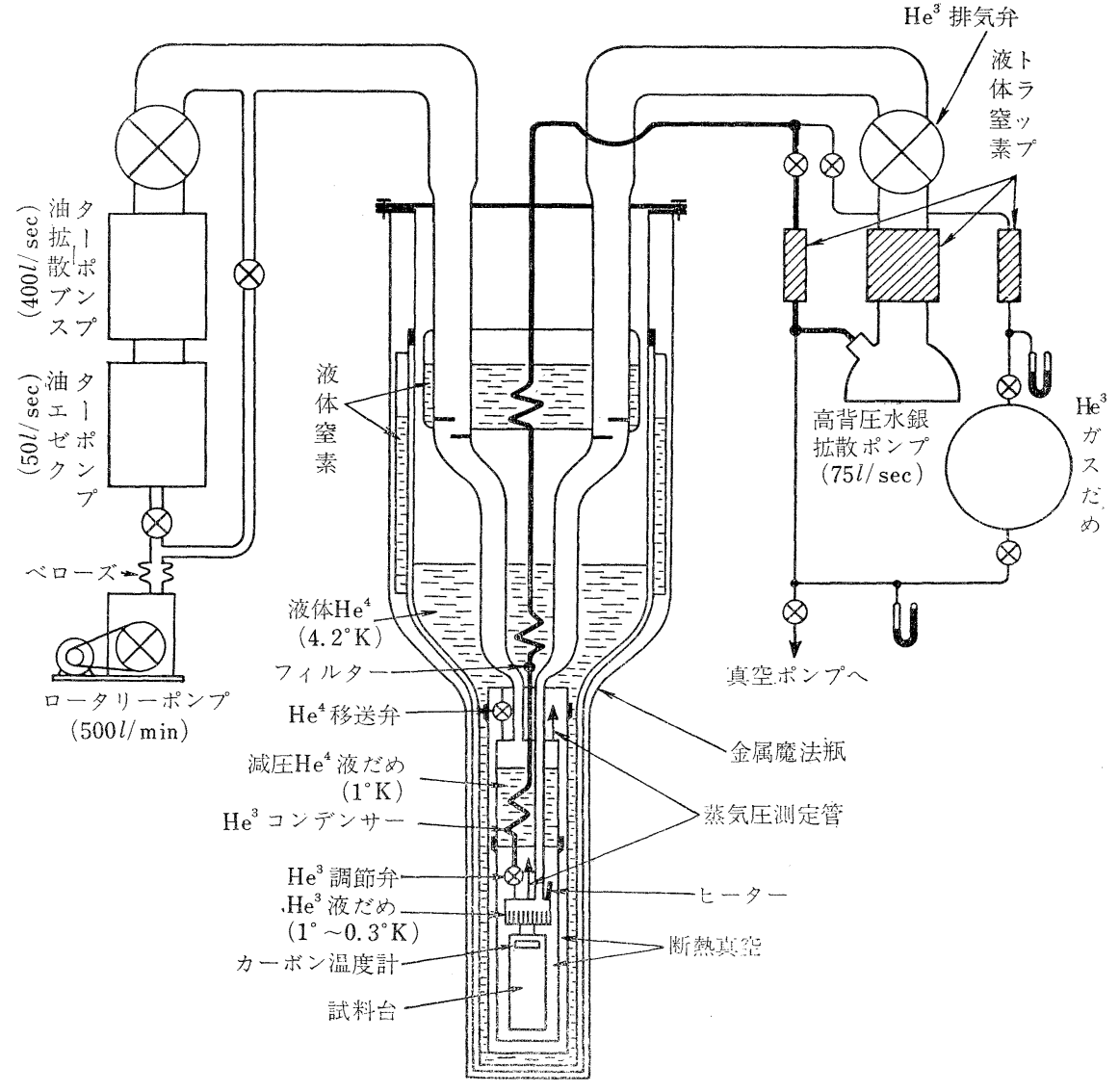

第 1 図 $\mathrm{He}^{3}$ 冷凍機 の構造

Vol.3 No. 5 (1968) 
射遮蔽板を入れると共に 2 ケ所で曲げてめる。（2）で は排気の效率を最もよくするために, $\mathrm{He}^{4}$ および $\mathrm{He}^{3}$ の排気管の直径を $50 \mathrm{~m} / \mathrm{m}\left(300^{\circ} \mathrm{K}\right), 26 \mathrm{~m} / \mathrm{m}\left(77^{\circ} \mathrm{K}\right)$, $12 \mathrm{~m} / \mathrm{m}\left(4.2^{\circ} \mathrm{K}\right), 6 \mathrm{~m} / \mathrm{m}$ ( $1{ }^{\circ} \mathrm{K}$ 以下) 94 段変觉て 各部のコンダクダンスをほぼ゙一定にした。（3）は特殊 な針状弁を用い，液体へリウムの流れをきわめて微細 に調節できるようにしたものである。(4) の $\mathrm{He}^{3}$ ガス の予冷は, $77^{\circ} \mathrm{K}$ (内径 $2.5 \mathrm{~m} / \mathrm{m}$, 長さ $1 \mathrm{~m}$ ) と $4.2^{\circ} \mathrm{K}$ (内径 $1 \mathrm{~m} / \mathrm{m}$, 長さ $1.2 \mathrm{~m}$ ) で行ない, 予冷の最後の 部分にフィルター（\#400の金網を多く重ねたもの）を 入れて予冷を完全にすると共に，これより先の細いパ イプル，凝固した不純ガスやゴミなどが到達しない ようにしてある。 $\mathrm{He}^{3}$ のコンデンサーには, 内径 0.6 $\mathrm{m} / \mathrm{m}$, 長さ $50 \mathrm{~cm}$ の $\mathrm{Ni}-\mathrm{Cu}$ 管を 3 本並列につないだ ものを用いた。（5）は液体 $\mathrm{He}^{3}$ と $\mathrm{He}^{3}$ 液溜との間の 界面熱抵抗をできるだけ小さくするように, $\mathrm{He}^{3}$ 液溜 の内部に多くの同心円状のヒダを出して, 接触面積を 約 $80 \mathrm{~cm}^{2}$. 亿した。試料は $\mathrm{He}^{3}$ 液溜につながった銅の 試料台にはりつける。をた，測定用のリード線を伝っ て熱が流入してくるのを防ぐために，4.2\% $\mathrm{K}$ 扰よび 1 K のところにサーマルアンカーをを設けてある。

この装置に用いた主要附属品は, $\mathrm{He}^{4}$ の排気系には $400 \mathrm{l} / \mathrm{sec}$ の油拡散ブスターポンプ(日本特殊機械K.K.), $50 l / \mathrm{sec}$ の油エゼクターポンプ（日本特殊機械 K. K.) $500 \mathrm{l} / \mathrm{min}$ の油回転ポンプ（東京真空, 但し気密構造 飞改造）を用い, $\mathrm{He}^{3}$ の循環系には, 高背圧で $75 l / \mathrm{sec}$ の水銀拡散ブスターポンプ（イギリスEdwards High Vacuum LTD.の $2 \mathrm{M} 4 \mathrm{~A}$ 型）を用いた。これは背圧

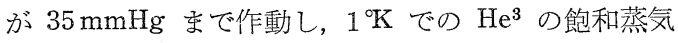
圧が $8.6 \mathrm{mmHg}$ であるので, このポンプは $\mathrm{He}^{3}$ のガ スを排気するのと，圧縮して液化する両方の役割を果 たすことになる。

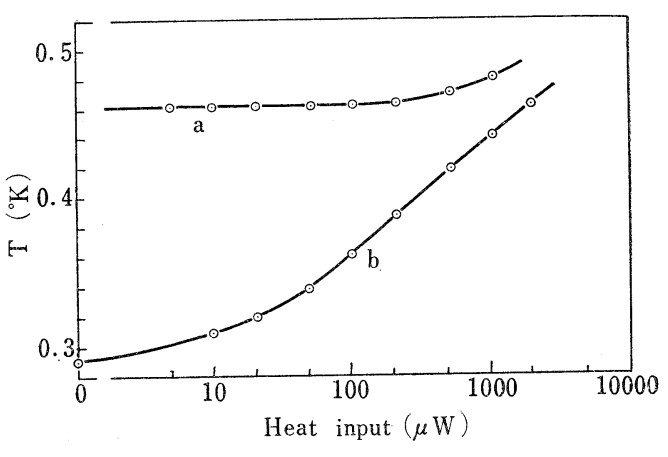

第 2 図 $\mathrm{He}^{3}$ 液溜に加えられた熱と温度の関係。 $a$ は極めて大量の $\mathrm{He}^{3}$ 循環を行なってい るとき，bは排気のみを行なった場合。

[動作状況]この装置の最低到達温度は $0.29^{\circ} \mathrm{K}$ で 各温度に和ける冷却能力そ第 2 図に示した。図で曲線 aはさわめて大量の循環を行なっている時の例で（循 環率〜 $\left.1 \times 10^{-4} \mathrm{~mole} / \mathrm{sec}\right), b$ は循環を行なわずに排気 のみを行なった場合である。循環量を減らせば曲線は $a$ から $b$ に近づいて行く。

減圧 $\mathrm{He}^{4}$ 液の温度は, 液の補給を行なわなければ, 0.89 〜 $0.9^{\circ} \mathrm{K}$ であるが，常時液の補給を行なっている 状態では $1.0^{\circ} \mathrm{K}$ である。使用している $\mathrm{He}^{3}$ の量は標 準状態で $700 \mathrm{cc}$ である。

測温方法は $\mathrm{He}^{3}$ の蒸気圧を較正用に用いて, 実際の 実験はカーボン抵抗温度計を用いている。ぬた温度調 節は循環率の調節とヒーターで行なっている。

[問題点]この装置の問題点は, $\mathrm{He}^{3}$ ガスの凝縮能 力がやや不十分なようで, 今の場合の数倍の能力を持 たせた方が色々な面で都合がよいと思われる。ちなみ に，この装置では標準状態で $700 \mathrm{cc}$ の $\mathrm{He}^{3}$ ガスの液 化は約 7 分かかる。

\section{大阪大学理学部大塚研究室}

極低温にして特殊な条件の下でのサイクロトロン共 鳴を行なう目的で, one-shot-type の $\mathrm{He}^{3}$ クライオス タットを製作した。以下アンケートの順に従って, 製 作上苦心した点和よび問題点などを和りこんで述べて みたい。

1）2）クライオスタット扎よび配管図は図 1,2 に 示す通りであるが, $\mathrm{He}^{4}$ の transfer に際しデュワー

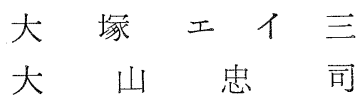

を取りはずし可能にするため,できるだけ軽量にするす よら努めた。

3）主要附属品について，性能およびメーカーを列 挙すると

$\mathrm{He}^{4}$ 減圧系 油拡散ポンプ $\left(\mathrm{O} \cdot \mathrm{D}_{1}\right) 800 \mathrm{l} / \mathrm{s}$ 油噴射ポンプ (O.B) $100 \mathrm{l} / \mathrm{s}$ キネーポンプ (K.P) $600 \mathrm{l} / \mathrm{m}$ 低温工学 


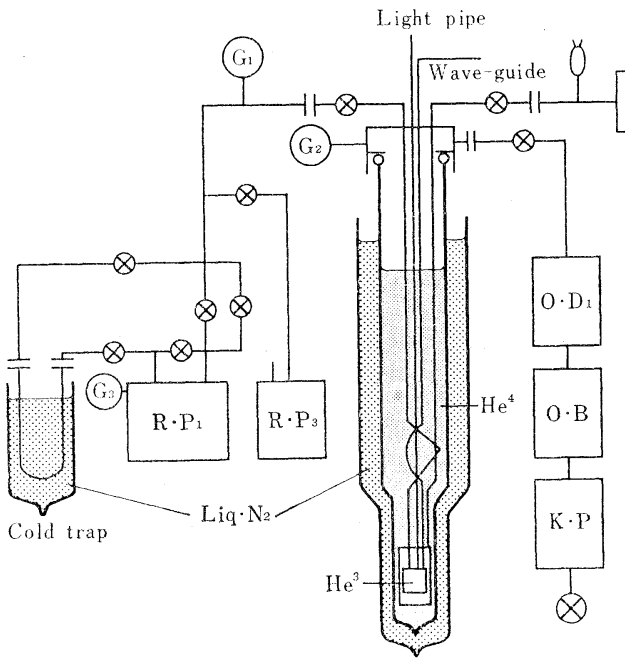

第 1 恳

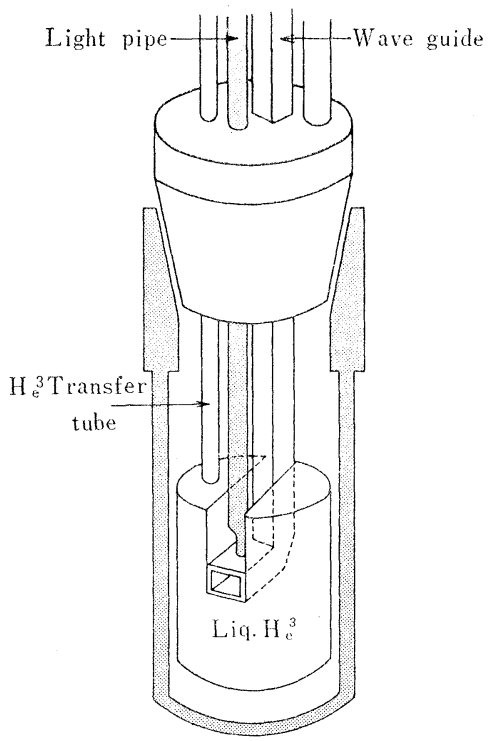

第 2 図

断蓺系 油扰散ポンプ $\left(\mathrm{O} \cdot \mathrm{D}_{2}\right) 400 \mathrm{l} / \mathrm{s}$

$$
\text { ロータリーポンプ }\left(\mathrm{R} \cdot \mathrm{P}_{2}\right) 300 \mathrm{l} / \mathrm{m}
$$

排気系 ロータリーポンプ $\left(\mathrm{R} \cdot \mathrm{P}_{3}\right) 150 \mathrm{l} / \mathrm{m}$

以上いずれも日本特殊機械製

$\mathrm{He}^{3}$ 液化系 ロータリーポンプ $\left(\mathrm{R} \cdot \mathrm{P}_{1}\right) 150 \mathrm{l} / \mathrm{m}$ 大亜真空技研

蒸気圧測定系 $\mathrm{G}_{1}$ 回転式マクレオードゲージ

(0.0001-10 $\mathrm{mmHg}$ )

$\mathrm{G}_{2}$ マクレオードミ二真空計

(0.001-10 $\mathrm{mmHg}$ )

いずれも岡野製作所
$\mathrm{He}^{3}$ ガス压計 $\mathrm{G}_{3}$ ブルドン管式連成計

(DAITO)

$\mathrm{O} \cdot \mathrm{D}_{2}$

$R \cdot P_{2}$

コールドトラップ 活性炭およびグラスウ

ールにより油蒸気などを取る。

4）到達温度に関しては, 実験の性䁚上（サイクロ トロン共鳴では光によって電子を励起する）極低温で は特に避けねばならぬ輻射を故意に導入しなければな らない。このため到達温度および蒸発速度には，かな りの制限を受けることは覚悟していたが，色ガラスフ ィルターの使用，またライトパイプには石英棒を用い ることにより，必要な波長領域だけを最少限進入させ ることによって, 亦る程度の成功は得られたと思う。 すなわち，通常の実験条件の下で（白色タングステン ランプ $10 \mathrm{~W}$ 照射）約 $0.55^{\circ} \mathrm{K}$ まで，また光を照射さ せない場合（室温からの黒体輻射は避けられない） $0.45 \%$ まで下がる。

5）冷却能力は上述の実験条件の下で約 3 時間，ま た光を照射させない場合にはほぼ外部の $\mathrm{He}^{4}$ の存続時 間だけ (約 6 時間) 実験できる。

6) $\mathrm{He}^{4}$ の温度はポンプ運転開始後, 30 分で約 1.2 ${ }^{\circ} \mathrm{K} \mathrm{He}$ の量が減少すると $1.15^{\circ} \mathrm{K}$ まで下がる。

7) $\mathrm{He}^{3}$ は $\mathrm{R} \cdot \mathrm{P}_{1}$ 上のガス溜め (約 $4 l$ ) に $1 / 2$ 気 圧で入れてあり，全部液化させると約 $5 \mathrm{cc}$ の液体と して凝縮する。

8） $\mathrm{He}^{4}$ の温度はマクレオードミ二真空計による蒸 気生測定できめる。おた $\mathrm{He}^{3}$ の温度はU字形真空計和 よび回転式マクレオードゲージにて測定。現在二次温 度計として Speer 抵抗を用い，ACブリッジ法による 温度測定回路を製作中。

9）まえがきで述べたように極低温でのサイクロト ロン共鳴。

10）現在まで約三十回液化させたが， $\mathrm{He}^{3}$ のリーク もなく運転状沉は上々である。問題点としては, 実験 の性質上とはいえ, 直接の輻射による最低温度の限界 拉よび運転時間などに改良の余地がある。

11）断熱室にはスリ合わせを用いているが，これま での経験ではシリコングリスを徐々に冷却固化させる と入点以下でスーパーリークがしばしばある。しかし 液体窒素で急冷することにより，ほとんどリークは避 けることができた。

終りにこのクライオスタット製作に際して，大阪市 大の信貴豊一郎氏，電気試験所の佐々木亘氏にいろい ろ有益な助言を頂きました。ここに厚く誩礼申し上げ ます。 